\title{
The Growing of Eucalypts on Short Rotation in Brazil
}

\author{
by \\ Ron D. Ayling ${ }^{1}$ \\ \& \\ Paul J. Martins ${ }^{2}$
}

\begin{abstract}
This paper outlines the procedures used for the establishment and maintenance of Eucalyptus crops in Brazil. Wood fibre is grown primarily for charcoal production for iron and steel industries in many areas of southern Brazil. The first harvest is ready as early as five years after planting and is frequently followed by two or more harvests of coppice crops. Mean annual increments are often as high as $20-40 \mathrm{~m}^{3} / \mathrm{ha}$ and large yields are possible within a few years. The demand for eucalypt wood fibre in lieu of native species, and the high yields attained, justify the investments in land, nursery operations, and plantation cultural treatments.
\end{abstract}

\section{Résumé}

$C_{\theta}$ document donne les grandes lignes des techniques utilisées dans I'implantation et l'entretien des cultures d'Eucalyptus au Brésil. La fibre sert d'abord pour la production de charbon de bois utilisé en sidérurgie brésilienne. La première récolte survient après seulement 5 ans de plantation et souvent elle est suivie par au moins des coupes de taillis. Les accroissements annuels moyens sont souvent entre 20 et $40 \mathrm{~m}^{3}$ à l'hectare et des hauts rendements sont possibles après quelques années seulement. La demande pour la fibre d'Eucalyptus en place des essences des indigènes et les hauts rendements obtenus, justifient les coûts d'investissement pour le traitement du site, les opérations de pépinières, la plantation et les soins culturaux.

\section{Introduction}

In many countries of the tropics and subtropics one of the most pressing forestry problems is the growing demand for timber for local use as fuelwood and charcoal. Arnold and Jongma (1978) reported that wood as a fuel accounts for some $85 \%$ of all non-commercial energy used in developing countries. In 1971 for example, the total annual output and consumption of wood as a fuel was nearly 1,200 million cubic metres. In regions where forest resources are still quite abundant, the average annual per capita wood consumption is almost one cubic metre. Such high usage places a considerable burden on the indigenous forests, and as is frequently the case, the demands by wood-using industries and large rural populations cannot be met by any rational exploitation of these forests. Reliable regeneration of the native forest is often unsuccessful without expensive enrichment planting and managing on a sustained yield basis is very difficult. Many native species in natural stands are also notoriously slow growing in comparison with tropical plantations which often produce annual volume increments in excess of $40 \mathrm{~m}^{3} / \mathrm{h}$ a when managed on $10-20$ year cycles (Evans, 1976)

Plantation culture is thus a logical introduction to the tropics and there is considerable investment in the establishment of fast-growing exotic species to reduce the

\footnotetext{
${ }^{1}$ Asst. Prot, of Forestry, University of Toconto, contracted by the Canadian International Deveicoment Agency (CIDA) and the Universidade Federal de Vicosa, Brazil

${ }^{2}$ Forestry Student, University of Toronto, employed by the Companhia Agricola e Florestai of Minas Gerais, Brasit.
}

pressures on native forests threatened with extinction as well as to offset expensive imports of wood products, particularly pulp and paper. One of the most important and versatile tree genera for use throughout the warm-temperate and tropical countries is Eucalyptus. Species of this genus are capable of adapting and thriving under a variety of often exacting site conditions and one of their outstanding characteristics is the early age at which high yields are possible. Plantations of Blue Gum (E. globulus Labill.) in Italy showed annual volume increments of $32.5 \mathrm{~m}^{3} / \mathrm{ha}$ at six years of age (Gemignani, 1967); Maiden's Gum (E. maidenii F. Muell) averaged $30.0 \mathrm{~m}^{3 / 2}$ ha/yr in Zaire, and increments for Sydney Blue Gum ( $E$. saligna Sm.) in South Africa ranged from 15.0 to $35.0 \mathrm{~m}^{3} / \mathrm{ha} / \mathrm{yr}$ (F.A.O. 1975).

In this paper we discuss the operations associated with the growing of eucalypts on short rotation in Brazil. Data and information are presented which, to the best of our knowledge, have never appeared in any English-language publication on eucalypt culture and will be of interest to Canadian foresters. We make the suggestion that the growth rates and high yields characteristic of many Brazilian plantations are achieved only through sound nursery practices, careful selection and preparation of planting sites, and thorough cultural treatment during the life of the plantation, operations which are highly labour-intensive.

\section{Brazilian Incentives for Plantation Establishment}

The introduction of eucalypt species in Brazil began in 1904 by Edmundo Navarro de Andrade in the southern State of Sao Paulo with seed of 95 species collected from a limited area in Australia. The early planting of so many species in close proximity however, resulted in extensive hybridization and seed of mixed parentage did not always give beneficial results in plantations. (Fishwick, 1975). It was not until the mid 1960's that interest was shown in the establishment of plantations on a large scale using seed from known sources, partly becauce of the discouraging growth of earlier eucalypt plantations as well as the rapid depletion of valuable stands of the indigenous Parana-pine (Araucaria angustifolia (Bertoloni) Kuntz) in southern Brazil. Prance (1977) noted for example, that in the large industrialized Sao Paulo state less than $5 \%$ of the original forest cover remains today as a result of intensive forest clearing for agriculture and industrial purposes. Additional impetus for plantation establishment came with the passing of government legislation in 1966 providing fiscal incentives to companies for reforestation projects, and with the creation of the Brazilian Institute of Forest Development in 1967 to monitor these laws and to carry out associated research. In the 10-year period 1967-77, more than 1.5 million hectares of eucalypts were established (Brasil, 1978) and Berutti (1975) reported that more than $50 \%$ of all plantations started throughout the country by the early 1970 's were with eucalypts, and in Sao Paulo state, $83 \%$ of all plantations were eucalypts on short rotation, exceeding by number and area all plantations of exotic pines (mainly Pinus elliottii Engelm, and $P$. taeda L.).

Today these extensive areas of fast growing eucalypt help to reduce the cutting in native stands, and also provide 
reliable material for charcoal which is used in the iron, steel, and mining industries. According to the data of Azambuja and Thibau (1973), the nation-wide production of charcoal (dollar value) in 1970 ranked just below that of rice and corn, and well ahead of such traditional Brazilian crops as coffee and sugar-cane. Some 18 million cubic metres of wood were consumed from both native and eucalypt forests, providing more than 6 million cubic metres of charcoal. It has been estimated that by the early 1980 's, the annual industrial demand for charcoal will be 18.9 million cubic metres, and by 1985, more than 21.7 million cubic metres will be required (Brasil, 1976).

The incentives for plantation establishment are thus clearly present and Brazilian forestry companies have embarked on major reforestation projects of national significance.

\section{Ingredients for Success - Land, Labour, and Climate}

Brazil's central region is considered to be the country's most important area for eucalypt culture largely because of the rich deposits of iron-ore, and iron and steel manufacturing are vital components of the national economy. More than $70 \%$ of the wood grown in the large central state of Minas Gerais is for charcoal production with the balance to be used for pulp and paper, lumber, and mine props. The interest in this region by forestry companies is also related to the availability of large tracts of inexpensive land, flat to gently rolling for the most part, making some mechanization possible.

The area also has a large, poor rural population and the national government has an active interest in all forestry developments here. Leite (1978) has estimated that more than 400,000 rural poor are directly involved in various aspects of plantation culture for the charcoal and cellulose industries, and in recent years, more than 30,000 new jobs have been created annually.

Most of this central region is termed cerrado, areas variously covered by coarse grasses and low shrubs, with scattered patches of forest vegetation along watercourses and low-lying valleys. Portions of the region are highly eroded due to poor land-use practices and in Sao Paulo for example, the failure of coffee crops on marginal sites leaves the soil impoverished and the land is abandoned to weedy vegetation. In the drier northeast, cattle raising and some agriculture are carried out. Climatic conditions vary greatly over such a broad expanse of country where eucalypts are grown, from the cool humid subtropical zones of central Sao Paulo and the higher areas of Minas Gerais, to the tropical semiarid and arid regions of the north and northeast. Frosts are either absent or very rare in all parts of the cerrado and most regions have a distinct dry season, often of several months duration. Water is not a limiting factor in plant growth, and the xeromorphic characteristics of the natural vegetation are attributed to the acidity and low fertility of the soils, especially in available nitrogen and phosphorous (Arens, 1958). The soil surface layer over much of the area readily dries out, and because of the low colloidal content, forms a hardcap which must be penetrated by plant roots before the onset of the dry season (Ferri and Coutinho, 1958). The natural vegetation has adapted well under these conditions, reproducing vegetatively by means of suckers and underground tubers or, in the case of the wide-spread Leguminosae, having seeds which remain viable in the ground for many seasons.

The successful establishment of eucalypt species has been possible in the cerrado as the genus as a whole is not very site demanding and several species can be selected to suit various climatic zones. Although the potential wood yield should be $20-40 \mathrm{~m}^{3} / \mathrm{ha} / \mathrm{yr}$, the actual growth of some plantations has been much less. This has been attributed to the use of seed of inferior quality and to inadequate species or provenances being planted. The recent ecological zoning of central Brazil by Golfari (1978) of the Food \& Agricultural Organization will be a major contribution to successful plantation establishment in the cerrado.

\section{Thorough Site Preparation is Essential}

In addition to matching particular species to planting zones, eucalypt growth potential in the cerrado may be realized only after intensive site preparation. The use of heavy machinery to break up the upper soil hardcap allows seedlings to extend their root systems into lower horizons where permanent ground water is available. One of the reasons for the high survival and rapid growth of such species as Eucalyptus saligna and E. grandis W. Hill ex. Maiden, two of the principal species planted for charcoal production, is their agressive root growth, estimated to be as much as 2 metres within 3 months following planting (Ferri, 1955).

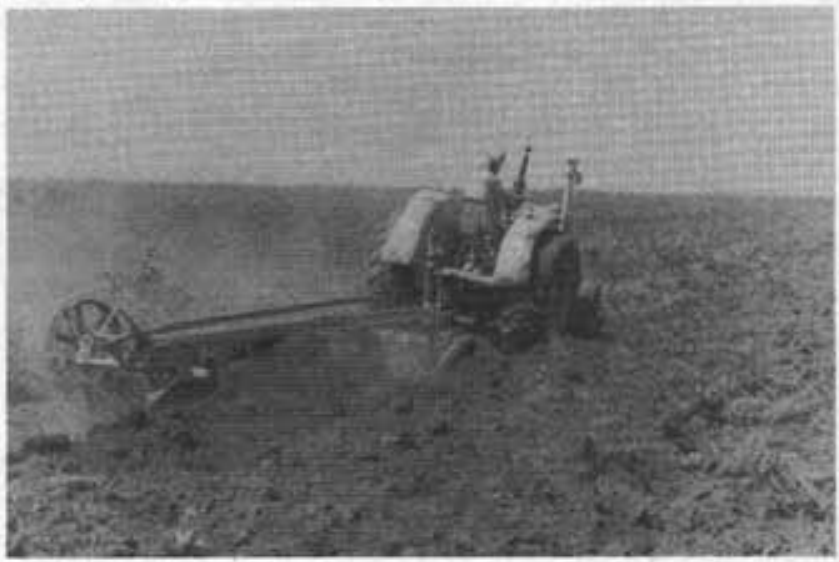

Figure 1. An aeration or ploughing operation in the cerrado region of Minas Gerais by the Companhia Agricola e Florestal (CAF).

In the cerrado region, the type of natural vegetation determines the method of site clearance and to a great extent gives an indication of inherent site fertility. Forest and scrub woodland, although more difficult and expensive to clear, are usually found on more fertile areas as compared with grasslands and open thorn forests. The most common soil types for eucalypt culture are the terra roxa solls, red-yellow and red-brown latosols, high in iron and aluminium oxides and generally deficient in exchangeable bases. These soils are deep, with a fine structure free of any compacted horizons except for often a surface hardcap. Usually the darker red the soil (the higher the iron oxide content), the more suitable the site is for growing eucalypts. Most species of the genus require good internal and external drainage although E. camaldulensis Dehnh. may develop well on sites with impeded water movement (Golfari, 1975).

Site preparation of scrub woodlands and areas of degraded forest requires the use of large bulldozers to push the woody vegetation into windrows for burning. Where vegetation is very dense, a heavy chain up to $120 \mathrm{~m}$ long is drawn twice over the area by two tractors working $25 \mathrm{~m}$ apart. After these knock-down operations, any useable material may be cut for charcoal kilns operated by local farmers. This often represents a significant reduction in site preparation costs and may provide as much as $25 \mathrm{~m}^{3} /$ ha of wood, yielding about $10 \mathrm{~m}^{3}$ of low quality charcoal (Simoes et, al., 1976).

After the residual vegetation is burned, the soil is thoroughly prepared. One of the largest forestry companies working in the cerrado region, the Companhia Agricola $e$ Florestal (CAF), employs 6-7 wheeled tractors operating in 
single file to plough and disc the soil. Soils with a high clay content are ploughed to a depth of $35 \mathrm{~cm}$ by means of $70 \mathrm{~cm}$ diameter disc blades while, in sandier soils, only light ploughing with numerous small-diameter blades is necessary. Ploughing turns up stumps and roots of the weedy vegetation which are removed and burned, and serves to improve the overall soil structure. Some companies also apply lime at this point to reduce acidity. Discing or grading following ploughing using 12-16 small-diameter blades breaks up heavy sod to a depth of $12 \mathrm{~cm}$ (Figure 1). Site preparation on old farmlands and grasslands involves ripping the soil surface by ploughing to a depth of $20-45 \mathrm{~cm}$ and then leveling. Grass vegetation is usually controlled if ploughing is at least $10 \mathrm{~cm}$ deep. done when the soil is moist.

The result of both ploughing and discing operations is an excellent soil medium for maximum early root development and a level site for the use of planting machinery.

\section{Healthy, Vigorous Growing Stock Within Months}

Seedlings are planted when they attain heights of 20-30 cm, usually after only 70-90 days in the nursery. In the humid coastal regions, companies may first raise the stock in seedbeds to be later transplanted to individual containers. In the dry interior however, seedlings are raised directly in bags of clear, light-weight polyethylene, approximately $8 \mathrm{~cm}$ wide by $15 \mathrm{~cm}$ long with a number of perforations along the sides. This avoids the elaborate preparation of seedbeds and the subsequent transplanting of stock - a major source of nursery losses in the past. Seedlings grown directly in bags do not require shade and large, healthy plants can be raised in a relatively short time (Simoes et. al., 1976) Container planting in the cerrado is also useful for lessening the pressures on nursery operations by extending the planting season over several months. The nursery work force can be kept at a constant level for much of the year, an important consideration in small rural communities.

In the nursery, the soil used for filling containers is a mixture of equal parts sand and clay and is obtained from the weed-seed free $B$ horizon from nearby areas. The low fertility of this soil is not important as fertilizer is applied in the nursery, and again to the seedlings at the time of planting. The soil is sieved and funnelled into bags using a simple foot-operated machine called a moega, operated at a rate of some 9,000 bags per 8 -hr working day. Most Eucalyptus seed is extremely small ${ }^{3}$ and is sown together with the chaff - unfertilized ovules, fruit and leaf pieces. There is usually far more chaff than seed in commercial seedlots, with a variable number of viable seeds, and many companies therefore sow $40-50 \%$ more containers than needed. This provides a margin of safety and permits rigorous selection of seedlings for planting. When expensive seed is used, the surplus seedlings are often re-bagged, placed under shade. and used to supplement the selected planting stock. One difficulty in seedling production is to obtain an adequate supply of good quality seed and most companies import their seed from Australia and other countries. As plantations of suitable Brazilian stock mature however, the dependency on expensive foreign seed will decrease.

Table 1 is a detailed presentation of all related nursery operations. It should be noted that in addition to the necessary fertilizer applications, complete control of weeds, fungal spores, and numerous insect pests is important for a healthy and vigorous crop.

\footnotetext{
3 One kilogram of seed plus chaff of E. grandis may only be $10-20 \%$ seed (commercial seedlot) while a kiogram of pure seeds may contain 400,000 to nearly 700,000 seeds (Prol. Eduardo Borges, Dept of Forestry. University of Vicosa. Brazil. Personal com munication, May, 1980)
}

Table 1. Nursery procedures for eucalypt species

\begin{tabular}{ll}
\hline Day & Operation \\
\hline-4 & Aldrin insecticide ( $5 \%$ powder) is spread on soil
\end{tabular}
surface where bags will be placed in order to control ants, termites and other soil pests. Rice husks, to be used as a mulch cover, are disinfected with methyl bromide.

-3 Soil-filled bags are placed in seedilings bays, $1 \mathrm{~m}$ wide $\times 50 \mathrm{~m}$ long, and approximately 500 bags $/ \mathrm{m}^{2}$ Bags are watered with N-P.K $(4-16-4)$ at a rate of $0.25 \mathrm{~g} / \mathrm{bag}$

-2 Benlate fungicide at $0.4 \mathrm{~kg} / \mathrm{ha}$ in water is sprayed over bags to prevent germination of fungal spores.

$0 \quad$ Bags are topped with fine soil, watered well, and sowing of seeds is carried out with a handoperated sowing syringe, regulated for each species' seed size. About $4-6$ seeds are sown in each bag.

+1 An insecticide such as Folidol-60 at $0.7 \mathrm{~L} / \mathrm{ha}$ in water is used to control ants, beetles and caterpillars. This is repeated every 7 days. Methyl bromide at $4 \mathrm{cclm} \mathrm{m}^{2}$ is used for leaf-cutting ants.

+2 Fungicides such as Ferban \& Dithane M45 at $3 \mathrm{~kg} / \mathrm{ha}$ are applied every 4 days up to day 20 to control Cylindrocladium fungi species. If dampingoff occurs, Benlate is applied every 3 days until controlled.

$+5-10$ Germination begins and for most species is over within 3 weeks.

+25 Seedlings are thinned to one/bag when approx. $4 \mathrm{~cm}$ high, selection done on the basis of vigor, form, and central location in the bag. Surplus seedlings may be replanted and placed under shade. After this first selection, additional N-P.K (4-16-4) at $0.25 \mathrm{~g} / \mathrm{bag}$ is applied. Irrigation to this point may have been as frequent as 3-4 times each day. Once selection is made, the rate of watering is reduced to begin the process of hardening-off to enable the plants to withstand heat and water shortages encountered in the field.

+40.50 A second selection is made when seedlings are about $10 \mathrm{~cm}$ high, Irrigation is reduced to a minimum

+70.90 A final selection is made when seedlings are 20-30 $\mathrm{cm}$ in height, and the crop is ready for field planting.

Note: Additional N-P.K at 0.25 g/bag may be given anytime after day 25 if growth has been poor due to adverse climate. In periods of excessive rain, seedling top growth may be too rapid and the plants are awkward to handle in the field. Seedlings may be pruned back to $6-30 \mathrm{~cm}$. This assists hardening-off and can be done several times without any deformities developing (FAO, 1976). This pruning is a useful operation if nursery supply exceeds field demand.

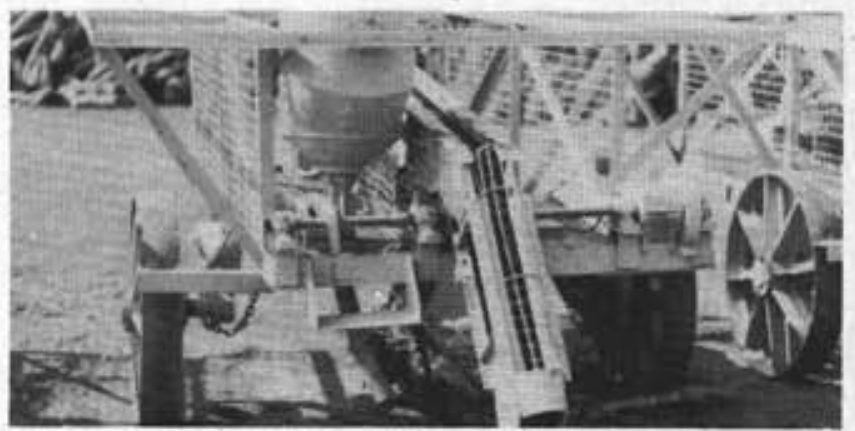

Figure 2. The plantadeira cuts a shallow furrow and distributes both fertilizer and container stock at regular intervals along the planting line. The ac. tual planting must still be done manually. 


\section{Plantations Often Extend Several Square Kilometres...}

The Eucalyptus plantations are monocultures and are managed as coppice forests. The first harvest may be made only $5-10$ years after planting, depending on the species, spacing, and the growth of the plantation.

Planting can be done throughout the year in the cerrado region but most companies try to plant before the-start of the spring rains or early in the wet season. In hot, dry periods, it is common practice to water the crop using a tanker truck, and within a few days the roots start to spread and the seedlings will then survive several weeks without rain. Light, tractor-pulled machines called plantadeiras are used to p:epare shallow furrows and distribute seedlings, as well as prejetermined amounts of fertilizer and insecticide for termite control (Figure 2). Each machine operates with 15-20 workers assigned to plant the seedlings along the rows. The plants are removed from the plastic bags and planted with the soil-root ball intact. The ferilizer, a dry application of N.P.K (10-28-6), is mixed well into the soil about $10 \mathrm{~cm}$ from the seedling at the rate of $150-200 \mathrm{~g} / \mathrm{plant}$. An additional $150 \mathrm{~g} / \mathrm{plant}$ may be given two months after planting if initial seedling growth is poor. Phosphorous is usually supplied in higher proportions since this element is frequently least available. Young eucalypt seedlings respond well to fertilizer applications, and fertilization at the time of planting is essential for survival and good growth. Cromer (1977) noted for example, that Australian E. globulus plantations gave a 10 fold increase in wood production at two years of age and twice the height growth of control plots after fertilization with $\mathrm{N}$ and $\mathrm{P}$ at the time of planting. In Brazil, Mello et al., (1970) reported that the difference between controls and fertilized $E$. saligna stands was more than $33 \mathrm{~m}^{3} / \mathrm{ha}$ after two years. When harvested at five years of age, fertilized stands produced 266 steres/ha $\left(1\right.$ stere $=1 \mathrm{~m}^{3}$ of stacked wood $=35.3 \mathrm{ft}^{3}$ ). Although fertilization is expensive and somewhat time-consuming, Knudson et al., (1970) suggested that costs could be offset by a reduction in the number of weeding operations necessary as crown closure would occur earlier in fertilized stands. The time of stand closure also depends on the spacing however, and when spacing is excessive, the difference between fertilized and unfertilized stands may be minimal (Shultz, 1976). Up to a point, the closer the spacing, the greater the total volume yield and the smaller average stem diameters will be in the early years of production. For charcoal production, uniformity of stem size is important, and small diameter material is not only easier to handle in harvesting and kiln-loading operations, but the quality of charcoal and degree of charring is better than with large bolts of wood.

For plantations harvested at the end of seven years, the most common spacing is $3 \times 2 \mathrm{~m}$ (1667 seedlings/ha). The three-metre space between rows permits the use of weeding and harvesting equipment. Other spacings of $3 \times 1.17 \mathrm{~m}$ and $2 \times 1 \mathrm{~m}$ have also produced large yields at the end of four years, and Suiter et al., (1980) reported the good development of $E$. grandis established at $1 \times 1.5 \mathrm{~m}$. At the end of 32 months, the mean annual increment was $50.3 \mathrm{~m}^{3} / \mathrm{ha}$ compared to MAl values of $25.0 \mathrm{~m}^{3} / \mathrm{ha}$ for stands established at the conventional $3 \times 2 \mathrm{~m}$ spacing.

\section{Tending Operations Are Expensive But Essencial}

Spacing is important as it determines not only the time of harvest but also harvesting operations and cultural treatments. Weeding of stands established at $3 \times 2 \mathrm{~m}$ spacing is carried out several times until the crop dominates the site. On the very best sites, some eucalypt species attain heights of $4.5 \mathrm{~m}$ within 12 months and weeding beyond this time is seldom required (Simoes et al., 1976). On most sites of the dry interior however, weed control must be carried

out twice in each of the first two years and usually once in the third and fourth years.

Control of weed vegetation has a positive influence on survival and growth in the first year as eucalypts are sensitive to root competition. Tractor-pulled discs or rotary cutting drums are used to weed between rows and although these implements sometimes damage the superficial roots of the young plants, the seedlings recover. Weeding by hand, an operation called 'crowning', is done between trees to remove above ground portions of weeds $40 \mathrm{~cm}$ about the stem. In a study by Brandi et al., (1974), crowning took approximately three man-days/ha while eleven man-days/ha were required for complete weed removal, including underground tubers and roots. Although there was more than a $1.5 \mathrm{~m}$ height difference of 27 -month-old seedlings by weeding with the costlier method, Brazilian companies are satisfied with the results obtained by crowning.

On coastal sites and interior river valleys, deep rooted perennial grasses such as Panicum maximum Jacq. and dense bracken fern (Polypodium brasiliensis L.) are serious weed problems and often require five or more treatments in the first year of the plantation (Brandi et al., 1974). Weed control with herbicides is not employed in any forestry operations, including those in the nursery mainly because of the abundance of cheap labour. There is also a lack of technical information on herbicide usage in Brazilian eucalypt plantations although Miyasaki (1979) has considered glyphosate (Roundup) to be effective in controlling Panicum maximum and the amide herbicides, diphenamid, oryzalin, and pronamid, have been used safely in nurseries (Brandi et. al., 1977).

The most expensive tending operation associated with the maintenance of these short rotation crops is for protection against termites and leaf-cutting ants. Termites may be controlled in the nursery and at the time of planting by treating the soil with Aldrin insecticide. Leaf-cutting ants are more difficult to control and threaten almost all agricultural and plantation crops. Annual treatment of these pests may be a considerable part of a company's silvicultural costs (Table 2).

Table 2. Estimated costs of ant control for all forestry districts
$(308,969$ ha) by the Brazilian company Companhia Agricola e Florestal in 1978

\begin{tabular}{cc}
\hline Chemical & $\begin{array}{c}\text { Value in Canadian } \\
\text { Dollars }\end{array}$ \\
\hline
\end{tabular}

\section{Methyl bromide}

56,415 cans @ $\$ 2.90 /$ can $^{1}$

Granular bait

$90,328 \mathrm{~kg}$ @ $\$ 0.65 / \mathrm{kg}$

Heptachloride

14,952 litres @ \$1.48/L

Labour

$1,914,383$ man-hours @a

$\$ 0.45 /$ man-hr

$63,603.50$

$58,713.20$

$22,128,96$

$\frac{861,472.35}{\$ 1,105,918.01^{2}}$

Toornmodity \& wages are approcimate tigures

2 allowing for the very high rate of inflation in Brazil, and estimating conservatively $70 \%$ in 1978 \& 1979 , this sum in 1980 dollars is more than $\$ 3,200,000$ for all forest districts!

The two genera of leaf-cutting ants (Atta and Acromyrmex) are widely distributed throughout Brazil and large, well-established colonies produce several thousand queens, each one capable of starting a new colony. A heavy infestation of 10-12 colonies per hectare can defoliate an entire plantation and therefore ant control is a vital operation. Prior to any site preparation, areas are examined for the presence of colonies and a granular poison bait $(0.5 \%$ dodecachloride insecticide plus inert attractants) is spread along the major pathways leading into the colonies. The insecticide becomes activated in the moist underground chambers and causes the death of the ants and their fungal 
gardens within days following treatment. Approximately $10 \mathrm{~g}$ of bait/m² of colony, up to one $\mathrm{kg}$ for large $100 \mathrm{~m}^{2}$ colonies, is required for complete control.

Prior to planting and approximately one month after the site has been prepared, the area is again treated using liquified methyl bromide or hephachloride applied at several points of entry to any remaining colonies (Figure 3 ). A single ap-

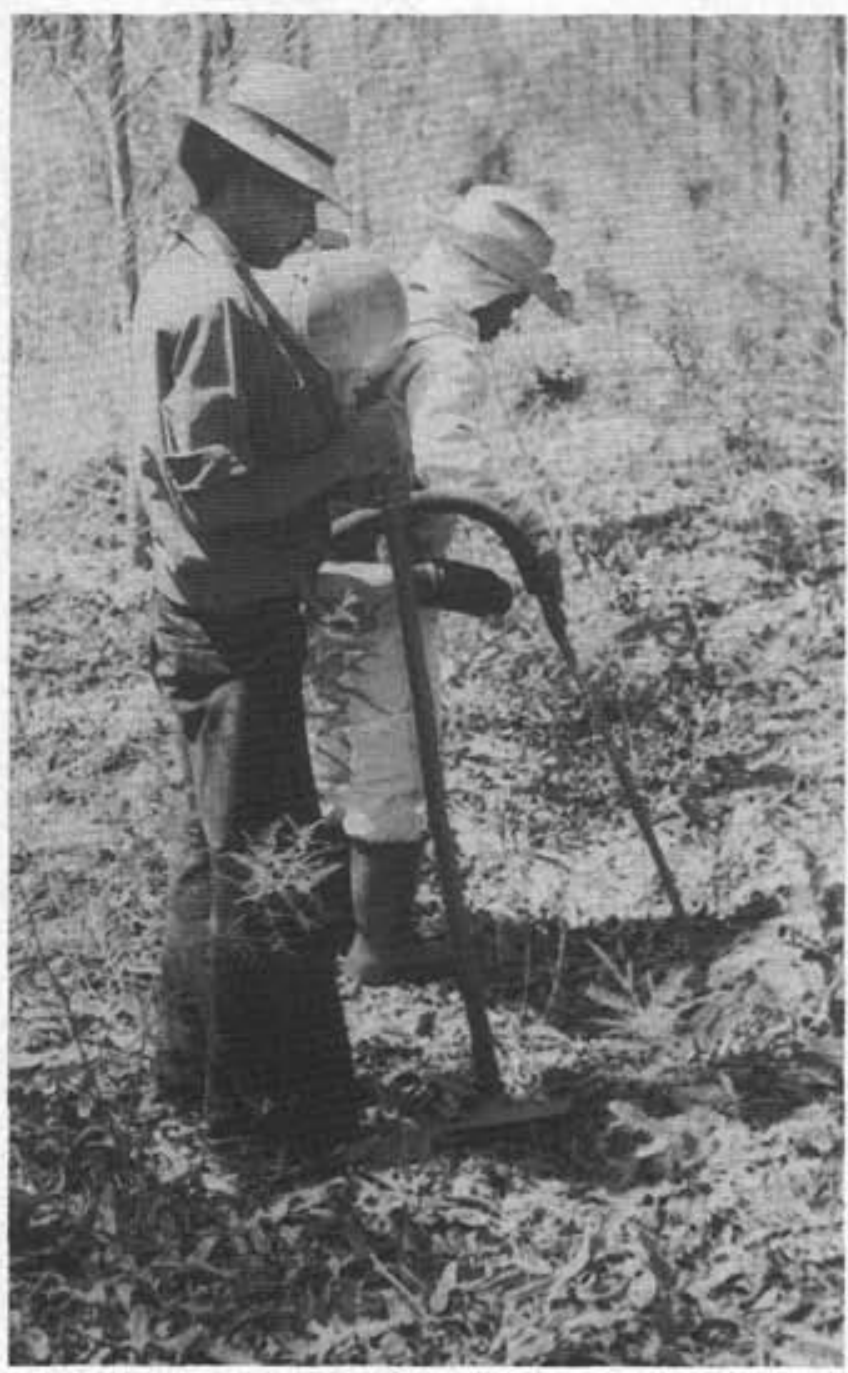

Figure 3. Ant control in a 3-year-old stand using a 'thermofogger' unit with heptachloride. One man clears the top of the colony of debris and covers any holes where smoke may be escaping, as the other applies the treatment. This is a fast and very efficient method of control.

plication of $24 \%$ heptachloride in diesel oil has been effective for complete control of major leaf-cutters (Santos et al., 1979). New colonies develop annually following the nuptial flights of queens from outside the treated areas, hence there must be continous examination of the plantations every six months. Although such monitoring keeps the number of colonies to a moderate $4-5 /$ ha, we accompanied a control operation in a 10 hectare $E$. grandis plantation and more than 100 colonies were located over the whole area. It required three hours for three 4 -man teams to thoroughly treat the plantation.

\section{Investments are Justified by The High Yields}

Although it is difficult and perhaps speculative to convert Brazilian cost figures to Canadian dollar values owning to inflation rates and differences in purchasing power between both currencies, we have attempted to show in Table 3 estimates for the various establishment operations. The most expensive items are seedling production and the planting operation, and although both could be mechanized further, this would displace much of the work force and seriously disrupt local economies.

Large yields are possible in only a few years (Table 4), and the harvesting of the initial seedling crop is commonly done in the seventh year after planting, to be followed by two coppice harvests. This ability of Eucalyptus to coppice and to do so reliably, makes it an outstanding genus for short rotation crops, and frequently more than two coppice cuts are possible, especially if the initial harvest is made earlier than the seventh year.

\begin{tabular}{cc}
\hline $\begin{array}{c}\text { Table 3. Estimated per hectare establishment costs (1978 } \\
\text { values) }\end{array}$ \\
\hline Operation & $\begin{array}{c}\text { Value in Canadian } \\
\text { dollars }\end{array}$ \\
\hline
\end{tabular}

Seedling production, including a $40 \%$ surplus

$\$ 90.40$

Knock-down operations, residual

burn, \& mechanical \&

manual site clearing

71.40

Harvesting \& stacking of

useable native material

Ploughing of site

Discing (grading) of site

Boundary \& planting line survey

Plantation access roads

Planting with the plantadeira

Irrigation of seedlings on site

Replanting if required (up to

$20 \%$ of the total)

Control of leaf-cutting ants

21.00

21.00

22.00

.40

12.50

131.85

17.80

3.90

26.75

$\$ 419.00^{1}$

this figure does not include the costs of weed control which is carried out later in the year.

Table 4. Average yields for various eucalypt groups over a 21 year rotation'.

\begin{tabular}{|c|c|c|c|c|}
\hline Species & Year $7^{a}$ & Year $14^{b}$ & Year $21^{\circ}$ & Total \\
\hline \multicolumn{5}{|l|}{ E. alba } \\
\hline E. grandis & 140.0 & 127.0 & 112.0 & 379.0 \\
\hline \multicolumn{5}{|l|}{ E. saligna } \\
\hline E. robusta & 123.0 & 113.0 & 98.0 & 334.0 \\
\hline \multicolumn{5}{|l|}{ E. microcorys } \\
\hline E. propinqua & 163.0 & 147.0 & 130.0 & 440.0 \\
\hline E. citriodora & & 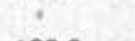 & & \\
\hline E. maculata & 110.0 & 120.0 & 88.0 & 318.0 \\
\hline \multicolumn{5}{|l|}{ E. tereticornis } \\
\hline E. camaldulensis & 106.0 & 88.0 & 85.0 & 279.0 \\
\hline \multicolumn{5}{|l|}{ Average for all } \\
\hline groups & 128.0 & 119.0 & 103.0 & 350.0 \\
\hline $\begin{array}{l}\% \text { decline in } \\
\text { productivity of } \\
\text { seedling crop }\end{array}$ & - & $7.0 \%$ & $19.5 \%$ & \\
\hline
\end{tabular}

${ }^{1}$ yields are $\mathrm{m}^{3} \mathrm{ha}$; based on data supplied by the Companhia Agricola e Forestaf apepresents the yield from the seediling crop

byield from the first coppice harvest

cyleid from the second coppice harvest

The best time of year for harvesting the seedling crop is in the winter or dry season when the root systems have abundant carbohydrate reserves to support subsequent coppice shoot (Briquelot and De Conti, 1975). The development of new growth from buds at the stump surface begins shortly after harvest (Figure 4) and within 10 months several shoots have become dominant (Figure 5 ). At this point, rigorous thinning to $2-3$ stems/stump is carried out. The coppice shoots have the advantage of a well established root system 


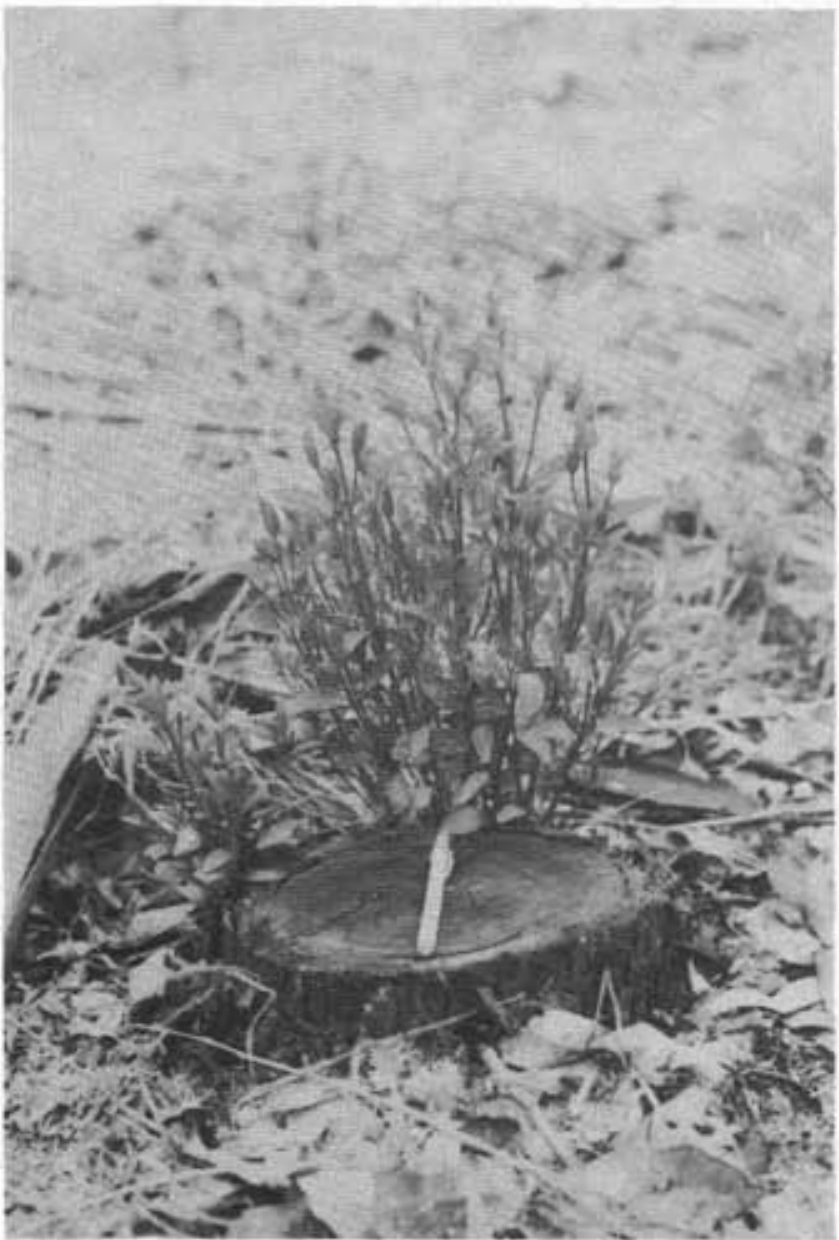

Figure 4. Coppice shoots of E. grandis two months after the harvest cut.

and usually outgrow any seedling planted at the same time. As Table 4 indicates, the volume obtained from successive coppice crops may be frequently less than the yield from the seedling crop but this is apparently not due to any decrease in stool vigor. In each coppice crop, a percentage of the stumps (5-10\% depending on the species) often fails to produce new shoots and this stump mortality plus excessive thinning of shoots ( 1 stem/stump) will reduce the overall basal area to less than that producing an optimum volume increment (Carter, 1974). If the coppice crop is lightly thinned, the volume loss through stump mortality is usually compensated by growth on bther stools. Carter (1974) has suggested that if it is necessary to obtain coppice yields similar to that of the seedling crop, the time of coppice harvest might be delayed by one or two years.
Consistently high yields however, especially over stems of widely varying diameters, are not required in charcoal manufacturing. The important charcoal properties of density, hardness, and moisture content are influenced more by wood density and size, and small-diameter material is preferred. E. grandis, although its density is relatively low $\left(0.45 \mathrm{~g} / \mathrm{cm}^{3}\right)$ is a favoured species because of its fast and uniform rate of growth and the ability of the species to coppice reliably.

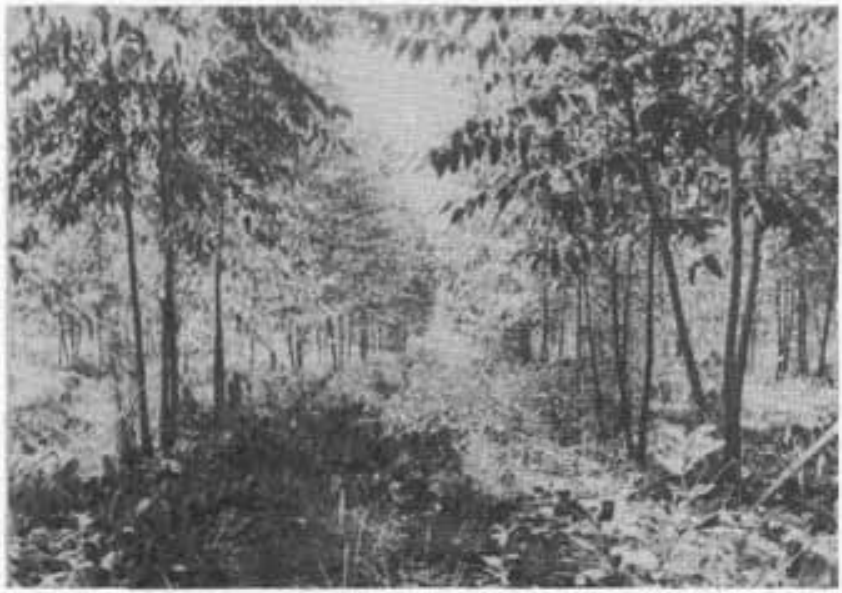

Figure 5. E. grandis coppice 10 months after harvest, thinned to $2-3$ stems/stool.

Table 5 presents yield information on a number of eucalypt species and hybrids, planted at various spacings and harvested at different times, and these data are compared to some familiar hybrid poplar clones in southern Ontario. In spite of our shorter growing season, the poplar data compares favourably with some eucalypt yields, especially those of the first coppice harvest.

The influence of spacing on wood volume is also shown in Table 5 (the work of Suite et al., with E. grandis) and the yields of two similar-species at the same spacing but harvested at different times ( $E$. alba and $E$. saligna).

Charcoal is produced by the partial reduction of wood under controlled conditions in large clay kilns (Figure 6). Each kiln has an average capacity of about $185 \mathrm{~m}^{3}$ of wood which yields between $65-80 \mathrm{~m}^{3}$ of high quality charcoal on an 8-day operating cycle. Large companies may have from 20 to 40 kilns in each forest district and can supply from 4,000 to more than $10,000 \mathrm{~m}^{3}$ of charcoal per month to steel and iron-ore industries.

Table 5. Mean annual increments and yields of Eucalyptus and Populus

\begin{tabular}{|c|c|c|c|c|c|}
\hline Spe & $\begin{array}{c}\text { Spacing } \\
(\mathrm{m})\end{array}$ & $\begin{array}{l}\text { Age } \\
\text { (yrs) }\end{array}$ & 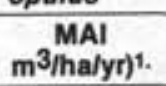 & $\begin{array}{c}\text { Yield } \\
\left(\mathrm{m}^{3} / \mathrm{ha}\right)\end{array}$ & Reference \\
\hline E. grandis & $1 \times 1.5$ & 2.7 & 50.3 & 134.1 & Suiter et al. (1980) \\
\hline E. grandis & $3 \times 2$ & 2.7 & 25.1 & 66.8 & " \\
\hline E. alba & $2 \times 2$ & 2.8 & 21.2 & 58.3 & Brasil (1976) \\
\hline E. alba & $3 \times 1.5$ & 3 & 15.3 & 46.0 & $n$ \\
\hline E. saligna & $3 \times 1.5$ & 6 & 26.4 & 158.1 & $"$ \\
\hline E. alba $X$ saligna & $2 \times 2$ & 6 & 31.4 & 188.6 & $*$ \\
\hline E. tereticornis & $2 \times 2$ & 6 & 31.9 & $191.3^{2}$ & 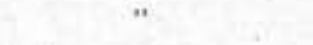 \\
\hline $\begin{array}{l}\mathrm{X} \text { alba } \\
\text { E. citriodora }\end{array}$ & $2 \times 2$ & 8 & 15.6 & 125.12 & $"$ \\
\hline P. X euramericana & $2.4 \times 2.4$ & 7 & 90.0 & 60.0 & Armson \& Smith (1977) \\
\hline P. alba $X$ davidiana & $2.4 \times 2.4$ & 9 & 21.0 & 190.0 & 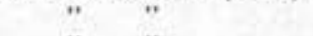 \\
\hline P. euramericana & $2.4 \times 2.4$ & 9 & 18.0 & 160.0 & $*$ \\
\hline
\end{tabular}

one cubic metre per hectare $=14.3$ cubic feet per acre

2 these values are tor the first coppice cut 


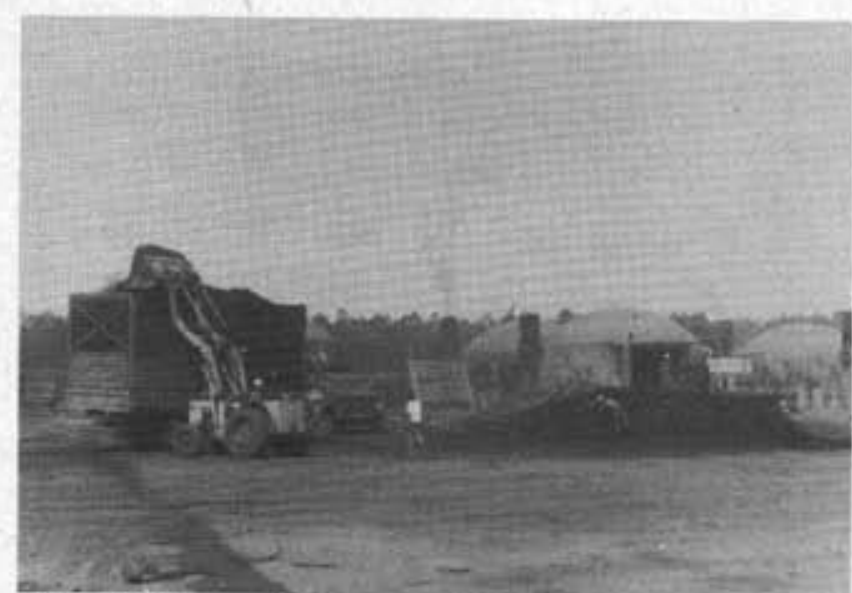

Figure 6. This charcoal production unit of 40 kilns manufacturers approximately $10,000 \mathrm{~m}^{3}$ montly. requiring more than $28,000 \mathrm{~m}^{3}$ of eucalypt wood. The charcoal is cooled for 48 hrs before it is sorted and loaded onto trucks for the trip to the steel mill.

\section{What Of The Future?}

The estimated cost of producing one cubic metre of charcoal (excluding plantation and nursery costs) is approximately $\$ 22.00$ (1980 Canadian dollars). This value includes timber harvesting costs, transportation costs of wood from the plantation and charcoal to nearby cities, and the actual charcoal production costs. A month's production of $10,000 \mathrm{~m}^{3}$ of charcoal however, is only sufficient for about two days of steel mill operation and hence the current supplies of wood from these short rotation eucalypt plantations are, in many instances, insufficient to meet local mill demands. Stands of native species must still be harvested to supply charcoal. The demand for charcoal continues to increase as existing iron-ore deposits are processed. Brazil has one of the largest known reserves of iron-one in the world, and both the production and export of iron and steel have risen dramatically in the last few years.

Besides their major use in some regions of Brazil for charcoal, Barrichelo and Brito (1976) have noted the suitability of E. grandis for sulphate pulp. Furthermore, in the carbonization process of eucalypt wood to charcoal, volatile substances such as methanol, acetic acid, and wood pitch may in time offset the costs of wood and charcoal production. With the increasing costs of imported fossil fuels, methanol especially may become very important to Brazilians. One hectare of eucalypt wood may yield up to 5.7 metric tonnes of methanol annually, and this has been mixed with ethanol (from sugar-cane) and added to gasoline for use in adjusted automobile engines (Almeida and Junqueira, 1979).

There are however, several problems associated with these short rotation plantations and one is the dependence on a large and relatively inexpensive work force in almost all aspects of plantation establishment and maintenance, and in charcoal production. While this labour remains cheap and abundant, mechanization will and should be given a low priority. An additional problem concerns what effect several successive crops may have on the nutrient status of planting sites. There is presently little reliable information available on the yields of first and second coppice harvests, although some data suggest a slight decline in productivity. Nutrients are added in the form of fertilizers at the time of planting, and again when logging slash is left on the sites after harvest but little is known on the effects of a short rotation eucalypt crop on site quality over time.
Brazil however, certainly has the right climate, abundant land, and the technical skills to take full advantage of such a unique genus as Eucalyptus, and if these potential problems are recognized and handled smoothly, the country may soon become one of the world's leading producers of wood fibre.

\section{Acknowledgements}

The authors wish to thank Dr Arno Brune of the Universidade Federal de Vicosa and Prof. Renato Brandi, Scientific Director of the Society of Forest Researchers for kindly reviewing this article and for their helpful comments. We are also grateful to the Companhia Agricola e Florestal of the State of Minas Gerais and to all its employees for the opportunity of visiting several forestry operations and for the support of Mr Martins while in Brazil. In particular, we thank Dr Jose Luiz de Magalhaes Neto, Company Director, and Dr Walter Suiter, Director of Research \& Silviculture for the company for their time and assistance.

\section{References}

Almeida, J.L. de and N. Junqueira. 1979. Energia liquida, gargalo do desenvolvimento (Liquid energy, the bottle-neck in its development). Jornal dos Reflorestadores 4:16-17.

Arens, K. 1958. O cerrado como vegetacao oligotrofica (The cerrado as an example of oligotrophic vegetation). Botanica 15: 59-77.

Armson, K.A. and J.H.G. Smith. 1977. Management of hybrid poplar. In: F.L.C. Reed \& Associates (Editors). Forest management in Canada. Vol. II, Case Studies. Forest Management Institute, Info. Rept. FMR-X-103, 1978. pp. 5.1-5.27.

Arnold, J.E.M. and J. Jongma. 1978. Fuelwood and charcoal in developing countries. Unasylva 29(118): 2-9.

Azambuja, D. de and C.E. Thibau. 1973. Diretrizes para o problema do carvao vegetal na siderurgia (Directives on the charcoal supply problem in the iron smelting industry). Instituto Brasileiro de Desenvolvimento Florestal, Boletin Tecnico IBDF-3, $102 \mathrm{p}$.

Barrichelo, L.E.G. and J.O. Brito. 1976. Potencialidade de especies tropicais de eucalipto para a producao de celulose sulfato branqueada (The potential of tropical eucalypts for bleached sulphate pulp). Instituto Brasileiro de Desenvolvimento Florestal, Piracicaba 13: 1-9.

Berutti, P.A. 1975. Aspectos do reflorestamento no Brasil (Aspects of reforestation in Brazil). Brasil Florestal 6(21): 3-7.

Brandi, R.M., N.F. de Barros and J.F. Candido, 1974. Comparacao de methodos de limpeza na formacao de Eucalyptus alba (Blume) Reinw., E. saligna Sm., e E. botryoides Sm. (A comparison of weeding methods in the development of stands of $E$. alba, E. saligna, and E. botryoides). Revista Ceres 21: 427-433.

Brandi, R.M., L. Couto, J.F. de Silva and J.M. Mlyasaki. 1977. Tolerancia de diversas especies de eucalipto $e$ alguns herbicidas (The tolerance of various eucalypts to some herbicides). Revista Arvore 1(2): 149-153.

Brasil, Ministerio da Agricultura. 1976. Centro de pesquisas florestais de regiao de cerrado - programacao tecnica (Technical program of the Centre for Forestry Research in the cerrado). Projeto de Desenvolvimento e Pesquisa Florestal, PRODEPEF No. 10, Brasilia. 155 p.

Brasil. 1978. Area plantada nos diferentes estados com recursos dos incentivos fiscais (Areas planted in the different states with the resources from the tax incentive laws). Revista Silvicultura, May-June 1978. pp. 9

Briquelot, A. and A. De Conti. 1975. Influencia de tipos de cortes e tecnicas de desbrotas no desenvolvimento de brotacao de Eucalyptus paniculata (The influence of the type of cut and techniques of coppice thinning on the development of $E$. paniculata coppice). Companhia Agricola e Florestal, Belo Horizonte. Internal Rept. $18 \mathrm{p}$.

Carter, W.G. 1974. Growing and harvesting eucalypts on short rotations for pulping. Australian Forestry 36: 214-225.

Cromer, R.N. 1971. Fertilizer trials in young plantations of Eucalyptus. Australian Forestry Research 5(2): 1-10.

Evans, J. 1976. Plantations: productivity and prospects. Australian Forestry 39: 150-163.

FAO. 1975. Pulping and papermarking properties of fast growing plantation wood species. Food \& Agriculture Organization, Rome. pp. 191-198 and pp. 221-234. 
FAO. 1976. Eucalypts for planting. Food \& Agriculture Organization, Rome (Second edition), 398 p.

Ferri, M.G. 1955. Problemas de reflorestamento da caatinga e do cerrado (Problems of reforesting the caatinga and cerrado areas). Ciencia e Cultura 7(1): 12-14.

Ferri, M.G. and L.M. Coutinho. 1958. Contribuicao ao conhecimento da ecologia do cerrado (Contribution to an understanding of cerrado ecology). Botanica 15: 103-150.

Fishwick, R.W. 1975. Forestry in Brazil. Commonwealth Forestry Review 54(1): 53-63.

Gemignani, G. 1967. Observations preliminaires sur acroissement de quelques especes d'eucalyptus dans l'agro pontino. In: World symposium on man-made forests and their industrial importance. Food \& Agriculture Organization, Rome. Vol. III, pp. 1959-1966.

Golfari, L. 1975. Zonamento ecologico do estado de Minas Gerais para reflorestamento (Ecological zoning of Minas Gerais State for reforestation). Projeto de Desenvolvimento e Pesquisa Florestal, FAO/1BDF 71-545, Serie Tecnica 3.

Golfari, L. 1978. Zoning for reforestation in Brazil and trials with tropical eucalypts and pines in the central region. FAO Project BRA 76-027, Brasilia. 42 p.

Knudson, D., J.E. Hayner and H. Correia. 1970. Fertilizing Eucalyptus on Brazilian savannah soils. Commonwealth Forestry Review 49(1):

Leite, N.B. 1978. Perspectivas do reflorestamento ante as necessidades e programas prioritarios do governo (Reforestation outlooks related to the requirements and priorities of the National Government). Proceedings of the IV National Meeting of Reforestation Workers, Campo Grande, Brazil. pp. 102-105.

Mello, H.A., J.S. Mascarenhas, J.W. Simoes and H.T.Z. Couto. 1970. Resultados da aplicacao de fertilizantes minerais na producao de madeira de Eucalyptus saligna $\mathrm{Sm}$. em soios de cer-

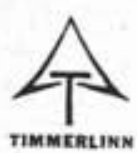

Tel.: (819) 326-3559

\section{TIMMERLINN 虫任}

PROFESSIONAL AND TECHNICAL SERVICES IN FORESTRY AND ENVIRONMENTAL SCIENCES

R.R. No. 2, STE. AGATHE DES MONTS, QUE. J8C $2 Z 8$ rado do Estado de Sao Paulo (Results of mineral fertilizer applications on E. saligna wood production on cerrado soils in Sao Paul State). Instituto Brasileiro de Desenvolvimento Florestal, Piracicaba 1: 7-26.

Miyasaki, J.M. 1979. Efeitos do nitrogenio e de diferentes fontes desse elemento na acao do glyphosate sobre o capim-coloniao (Panicum maximum Jacq.) (The effects of nitrogen and different nitrogen sources on the action of glyphosate herbicide on guinea-grass). Unpublished thesis, Universidade Federal de Vicosa, Brasil. $88 \mathrm{p}$.

Prance, G.T. 1977. Exploitation and conservation in Brazil. In: Hedberg, I. (Editor). Systematic botany, plant utilization, and biosphere conservation. Proceedings of a Symposium, Uppsala, Sweden. Almqvist \& Wiksell Pusblishers, pp. 146-149.

Santos, G.P., J.M. Gomes, J.C. Dominicio and R.M. Brandi. 1979. Contrôle de sauvas pelo sistema de termonebulizacao na regiao de Timoteo, M.G. (Control of leaf-cutting ants by thermofogger units in the Timoteo, M.G. region). Brasil Forestal 39: 18-20.

Schultz, C.J. 1976. A review of fertilizer research on some of the more important conifers and eucalypts planted in subtropical and tropical countries, with special reference to South Africa. South African Dept. of Forestry, Bulletin No. 53, 89 p.

Simoes, J.W., R.M. Brandi and J.R. Malinovsky. 1976. Formacao de florestas com especies de rapido crescimento (Establishment of stands of rapidly growing species). Projeto de Desenvolvimento e Pesquisa Florestal, PRODEPEF No. 6, Brasilia. $1974 p$.

Suiter, W., G.C. de Rezende and C.J. Mendes. 1980. Producoes de florestas de Eucalyptus de ciclo curto para fins energeticos (Produciton of short rotation Eucalyptus for energy sources). Sociedade de Investigacoes Florestais, Boletin Tecnico No. 3. $9 \mathrm{p}$.

\begin{tabular}{|c|c|}
\hline CONSULTING & $\begin{array}{c}\text { Industrial Forestry } \\
\text { FORESTERS } \\
\text { ENGINEERS }\end{array}$ \\
Service Ltd. \\
Centrally Located for \\
Western Canada's \\
Forest Industry \\
101 - 1595 FIFTH AVE. \\
PRINGE GEORGE, B.C. \\
TEL.: (604) S64-4115
\end{tabular}

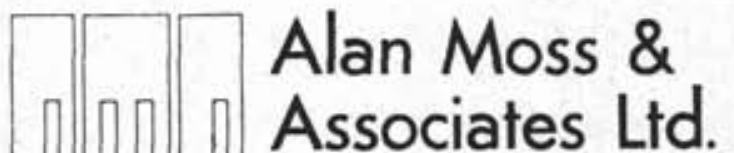

Consultants in Forestry and Forest Industries

\section{Domestic and International}

1334 St. Paul Street

Kelowna, British Columbia V1Y 2E1

Telephone: (604) 763-4811

Cable: Sylva

\section{Woodlot Service (1978) Ltd.}

"All Matters Pertaining to Forestry"

GORDON B. YOUNG, B.Sc.F., M.F.

Registered Professional Forester

320 Maple Street

Bus:: $506 \cdot 472-3396$

Fredericton, N.B. 